\title{
PENGARUH MOTIVASI MATERIAL DAN MOTIVASI NON MATERIAL TERHADAP SEMANGAT KERJA KARYAWAN DI PT DAYA ADICIPTA SANDIKA
}

\author{
Sumarsid
}

\begin{abstract}
In the analysis of these data, the authors collected data that can support research by distributing questionnaires to 35 respondents from all employees of Sales at PT Daya Adicipta Sandika, with the results of the study are:

The results of the analysis of the correlation coefficient obtained correlation coefficient value X1 Motivation Materials on Employee Morale was 0.630, and the correlation coefficient X2 Motivation Non Material to Employee Morale was 0.588, thus the motivation Material and Motivation Non Material has strong relationships and significant $(0.000<0,05)$ of the Employee Morale PT Daya Adicipta Sandika.

The results of the analysis obtained value of the coefficient of determination $(R 2)=0.529$, thus variables X1 (Motivation Material) and X2 (motivation Non Material) contributed 52.9\% to variable $Y$ (Employee Morale) in PT Daya Adicipta Sandika and the rest by $47.1 \%$ influence of other factors that are not the authors studied, for example, the influence of the leadership, work stress, and cooperative relationships between employees.

Furthermore, the research hypothesis testing that digunakann by $F$ test (simultaneous) showed that the significant value of the variable X1 is motivation motivational material and nonmaterial X2 is $0.000>5 \%$ (0.000>0.05), so Ho rejected and Ha accepted, meaning that simultaneously seek material and non-material motivation significant effect on employee morale at PT Daya Adicipta Sandika.

Similarly, through the t test (partial) obtained significant value for the variable X1 Material Motivational 0,001 $<5 \%(0.001<0.05)$ and a significant value for the variable X2 Non Material Motivation of $0.005<5 \%(0.005<0.05)$, and thus Ha (alternative hypothesis) is received and Ho (null hypothesis) is rejected. Meaning and Motivation Motivation Material Material Non partially significant effect on Morale Employees at PT Daya Adicipta Sandika.

Furthermore, the company provides compensation to employees who adapted the work performance and in early stages of the fair as a motivation that is material to boost employee morale, and should the Company give appreciation to employees who have been achieving, by giving awards for example in the form of an opportunity to develop themselves so that employees are encouraged to work harder.
\end{abstract}

Keywords: Motivation Material, Non Material Motivation and Morale

\section{PENDAHULUAN}

Dalam memotivasi karyawan, perusahaan harus mengetahui motif dan motivasi yang diinginkan oleh karyawan. Karyawan mau bekerja untuk memenuhi kebutuhan, material dan non material, kebutuhan fisik maupun rohani. Bila kebutuhani material dan non matrerial yang diterima karyawan semakin memuaskan, maka semangat kerja akan meningkat dan pada akhirnya akan 
meningkatkan kinerja karyawan, kejenuhan dalam melakukan pekerjaanpun dapat dikurangi. Karena sebagaimana kita ketahui bahwa manusia mempunyai berbagai kebutuhan. Kebutuhan ini tidak hanya terbatas pada yang bersifat kebendaan atau materiil tetapi juga ada yang bersifat non materiil terutama yang berkaitan dengan harkat, martabat dan harga diri seseorang. Setiap karyawan akan berusaha memuaskan kebutuhan non material berbarengan dengan kebutuhan materialnya. Berdasarkan pengalaman dan dari beberapa buku yang penulis baca, biasanya karyawan yang puas dengan apa yang diperolehnya dari perusahaan akan memberikan lebih dari apa yang diharapkan dan ia akan terus berusaha.

Oleh karena itu dalam melaksanakan tugasnya maka karyawan perlu diberikan motivasi sehingga semangat kerja mereka semakin meningkat. Semangat kerja merupakan keadaan yang harus ada bila aktivitas /proses kerja ingin berjalan lancar. Dengan adanya semangat kerja yang tinggi, maka tujuan perusahaan dapat tercapai sesuai rencana.

PT Daya Adicipta Sandika berupaya untuk meningkatkan kinerjanya melalui semua aspek, mulai dari pengelolaan manajemen perusahaan, sumber daya manusia, proses hingga inovasi dan teknologi yang senantiasa selalu berkembang. Salah satu cara yang dilakukan oleh perusahaan dalam menunjang tercapainya tujuan tersebut adalah dengan suatu kebijakan berupa pemberian motivasi material dan non material kepada karyawan sehingga diharapkan dapat meningkatkan semangat kerja dan pada akhirnya akan meningkatkan kinerja perusahaan.

\section{Asumsi}

Agar tidak terjadi persepsi yang salah terhadap permasalahan yang akan dibahas, maka penulis memberikan asumsi sebagai berikut :

a. Motivasi yang bersifat material di PT Daya Adicipta Sandika sudah terlaksana dengan baik yaitu dengan adanya THR, Jamsostek, Bonus (jika keadaan keuangan perusahaan baik) serta tunjangan-tunjangan lain

b. Motivasi material yang digunakan dalam pembahasan adalah take home pay yang diterima setiap bulan, dianggap mewakili seluruh kegiatan motivasi material.

c. Faktor-faktor lain yang mempengaruhi semangat kerja karyawan selain motivasi material dan motivasi non material tidak dibahas.

\section{TINJAUAN PUSTAKA}

\subsubsection{Pengertian Manajeman Sumber Daya Manusia.}

Manajemen sumber daya manusia merupakan bagian integrasi dari ilmu manajemen yang mengkhususkan 
perhatiannya pada masalah sumber daya manusia. Peran manajemen sumber daya manusia sangat menentukan bagi terwujudnya tujuan organisasi, berperan dalam proses produksi juga merupakan faktor penentu tercapainya atau tidak tercapainya tujuan dan sasaran yang telah ditetapkan perusahaan.Dan tujuan utama sumber daya manusia adalah untuk meningkatkan kontribusi manusia yang ada di dalam organisasi terhadap organisasi tersebut. Dalam mencapai tujuan, organisasi tergatung pada manusia yang mengelola organisasi yang bersangkutan, karenanya sumber daya manusia tersebut harus dikelola dengan baik.. Berikut ini akan diuraikan beberapa definisi Manajemen Sumber Daya Manusia dari para ahli diantaranya :

Menurut Malayu S.P. Hasibuan dalam bukunya Manajemen Sumber Daya Manusia, (2006, p. 10)“Manajemen Sumber Daya Manusia adalah ilmu dan seni mengatur hubungan dan peranan tenaga kerja agar efektif dan efisien membantu terwujudnya tujuan perusahaan, karyawan dan masyarakat".

Pengertian manajemen Sumber Daya Manusia yang diberikan oleh A.A. Anwar Parabu Mangkuprawira dalam bukunya Manajemen Sumber Daya Manusia Perusahaan, (2013, p. 2) ialah : "Manajemen sumber daya manusia merupakan suatu perencanaan, pengorganisasian, pengkoordinasian, pelaksanaan, dan pengawasan terhadap pengadaan, pengembangan, pemberian balas jasa, pengintegrasian, pemeliharaan, dan pemisahan tenaga kerja dalam rangka mencapai tujuan organisasi”.

Pengertian manajemen Sumber Daya Manusia menurut Garry Dessler (2004, p. 4) ialah : "Kebijakan dan praktik yang dibutuhkan seseorang untuk menjalankan aspek "orang" atau sumber daya manusia dari posisi seorang manajemen meliputi perekrutan, penyaringan, pelatihan, pengimbalan, dan penilaian".

Berdasarkan pengertian-pengertian tersebut di atas manajemen sumber daya manusia di perusahaan perlu dikelola secara profesional agar terbinanya keseimbangan antara kebutuhan pegawai dengan tuntutan dan kemampuan organisasi perusahaan. Dengan pengaturan manajemen sumber daya manusia secara profesional, pegawai yang diharapkan profesional ini harus dimulai sejak perekrutan pegawai, penyeleksian, pengklasifikasian, penempatan pegawai sesuai dengan kemampuan, penataran, dan pengembangan karirnya.

\subsection{Pengertian Motivasi}

Motivasi itu sendiri berasal dari kata latin "movere" yang berarti dorongan atau menggerakkan. Motivasi merupakan kegiatan yang mengakibatkan, menyalurkan dan memelihara perilaku manusia. Motivasi (motivation) dalam manajemen hanya 
ditujukan pada sumber daya manusia pada umumnya dan bawahan khususnya. Motivasi merupakan subyek yang penting bagi manajer, karena manajer harus bekerja dengan dan melalui orang lain. Manajer perlu memahami perilaku orang-orang tertentu agar dapat mempengaruhinya untuk bekerja agar sesuai dengan yang diinginkan oleh perusahaan. Motivasi adalah proses untuk mencoba dan mempengaruhi seseorang agar orang tersebut melaksanakan atau bekerja agar sesuai dengan yang diinginkan oleh perusahaan. Motivasi mempersoalkan bagaimana cara mengarahkan daya dan potensi bawahan, agar mau bekerja sama secara produktif dan berhasil mencapai serta mewujudkan tujuan yang telah ditentukan.

Seperti yang dituliskan oleh Heidjrachman dan Suad Husnan, dalam Manajemen Personalia (2008, p.197) :"Motivasi merupakan proses untuk mencoba untuk mempengaruhi seseorang agar melakukan sesuatu yang kita inginkan". Dan T. Hani Handoko (2008, p.252), mengatakan bahwa : "Motivasi keadaan dalam pribadi seseorang yang mendorong keinginan individu untuk melakukan kegiatan-kegiatan tertentu guna mencapai tujuan".

Dari kedua definisi motivasi di atas dapat disimpulkan bahwa motivasi pada dasarnya adalah pengaruh dari luar yang mendorong diri seseorang untuk bekerja dan berperilaku lebih giat dalam mencapai suatu tujuan.

\subsection{Teori Motivasi}

Teori-teori motivasi yang dikutip dan menjadi kerangka teori motivasi dalam penelitian ini diambil dari buku-buku manajemen dan manajemen sumber daya manusia dibatasi hanya beberapa pengertian motivasi yang dikelompokan menjadi 2 kelompok yaitu teori kepuasan (content theory) dan teori proses (process theory).

a. Teori motivasi kepuasan :Teori ini berdasarkan pada faktor-faktor kebutuhan dan kepuasan individu sehingga mereka mau melakukan aktivitasnya, jadi mengacu kepada diri seseorang. Teori ini mencoba mencari tahu tentang kebutuhan apa yang dapat memuaskan dan yang dapat mendorong semangat kerja seseorang. Semakin tinggi standar kebutuhan dan kepuasan yang diinginkan, maka semakin giat seseorang untuk bekerja. Teori kepuasan (content theory) dalam bukunya Malayu SP. Hasibuan (2006, p.152-167) dibagi menjadi dua kelompok yaitu :Teori motivasi klasik dari Taylor teori ini, motivasi pekerja hanya untuk dapat memenuhi kebutuhan dan kepuasan biologis saja, yaitu hanya dapat mempertahankan kelangsungan hidup.dan Teori Herarkhi (Need Herarchy) dari Abraham Maslow, teori ini kebutuhan dan kepuasan pekerja identik dengan kebutuhan biologis dan psikologis, yaitu 
berupa material maupun non material. Dasar teori ini adalah bahwa manusia merupakan makhluk yang keinginannya tak terbatas atau tanpa henti, alat motivasinya adalah kepuasan yang belum terpenuhi serta kebutuhannya berjenjang. Jenjang tersebut dapat dijelaskan dari yang paling rendah sampai yang paling tinggi sebagai berikut :

b. Teori Motivasi Proses yaitu teori ini berusaha agar setiap pekerja mau bekerja giat sesuai dengan harapan. Daya penggerak yang memotivasi semangat kerja terkandung dari harapan yang akan diperolahnya. Jika harapan menjadi kenyataan maka pekerja cenderung akan meningkatkan kualitas kerjanya, begitu pula sebaliknya. Menurut Malayu SP. Hasibuan (2005, p.151-159) ada tiga macam teori motivasi proses yaitu ;Teori harapan (expectancy theory),Teori ini dikemukakan oleh Victor H.Vroom yang mengatakan bahwa seseorang bekerja untuk merealisasikan harapan-harapannya dari pekerjaan itu, teori keadilan (Equity theory) merupakan daya penggerak yang memotivasi semangat kerja seseorang, jadi atasan harus bertindak adil terhadap semua bawahannya secara objektif. Jika prinsip ini ditetapkan dengan baik maka semangat kerja karyawan akan meningkat. Dan Teori pengukuhan (Reinforcement theory) yang didasarkan atas hubungan sebab akibat dari

prilaku dengan pemberian kompensasi.

\section{c. Motivasi Material dan Non Material}

Alat-alat motivasi (daya perangsang) yag diberikan kepada bawahan dapat berupa motivasi material (material incentve) dan motivasi non material (nonmaterial incentive). Menurut Malayu S.P.Hasibuan (2006, p. 150) : "Motivasi material (material incentve) adalah motivasi yang bersifat materiil sebagai imbalan prestasi yang diberikan oleh karyawan. Yang termasuk motivasi material (material incentve) adalah yang berbentuk uang dan barang-barang"

Motivasi non material itu merupakan suatu dorongan yang terdapat dalam diri individu atau seseorang yang bukan dalam bentuk uang, atau benda, yang mengakibatkan seseorang tersebut melakukan tindakan tertentu.

Menurut Malayu S.P.Hasibuan (2006, p. 150)

: "Motivasi non material (nonmaterial incentive) adalah motivasi (daya perangsang) yang tidak berbentuk materi. Yang termasuk motivasi non material adalah penempatan yang tepat, piagam penghargaan, perlakuan yang wajar, pemberian perhatian, partisipasi maupun persaingan".

Sedangkan menurut Heidjrachman dan Suad Husnan, (2007, p.159) alat-alat motivasi yang diberikan kepada karyawan dapat 
berupa : Material Incentive adalah motivasi yang bersifat materiil sebagai imbalan prestasi kerja yang diberikan oleh perusahaan kepada para karyawan. Yang termasuk material incentive adalah tyang berbentuk uang dan barang-barang. Dan Nonmaterial incentive adalah motivasi (daya perangsang) yang tidak berbentuk materi. Yang termasuk non material adalah penempatan yang tepat, pekerjaan yang terjamin, piagam penghargaan, bintang jasa, perlakuan yang wajar, dan sebagainya.

\subsection{Pengertian Semangat Kerja}

Semangat kerja pada hakekatnya merupakan perwujudan dari pada moral kerja yang tinggi. Oleh karena itu, sudah selayaknya apabila setiap perusahaan selalu berusaha agar karyawan mempunyai moral kerja yang tinggi, sebab dengan demikian diharapkan semangat kerjanya, dapat meningkat. Berikut beberapa pengertian tantang semangat kerja, yaitu :

Menurut M. Manullang (2005, p. 183), ada 2 cara untuk mendefenisikan semangat kerja. sebagai berikut: Semangat Kerja adalah kondisi dari sebuah kelompok dimana ada tujuan yang jelas dan tetap yang dirasakan menjadi penting dan terpadu dengan tujuan individu. Dan semangat kerja merupakan pemilikan atau kebersamaan, Semangat kerja merujuk kepada adanya kebersamaan. Hal ini merupakan rasa pemahaman dengan perhatian terhadap unsur-unsur dari pekerjaan seseorang, kondisi kerja, rekan kerja, penyelia, pimpinan, dan perusahaan

Menurut Malayu S.P. Hasibuan (2005, p 94): "Semangat kerja adalah keinginan dan kesungguhan seseorang mengerjakan pekerjaannya dengan baik serta disiplin untuk mencapai prestasi kerja yang maksimal".Sedangkan menurut Alex S. Nitiasemito (2006, p 96): “Semangat kerja adalah melakukan pekerjaan secara lebih giat sehingga pekerjaannya dapat diharapkan lebih cepat dan lebih baik".

Berdasarkan pengertian-pengertian di atas, maka dapat disimpulkan bahwa semangat kerja merupakan alat penggerak atau pendorong karyawan untuk giat melakukan pekerjaan yang diberikan perusahaan dengan harapan agar karyawan dalam dirinya timbul dorongan yang lebih besar untuk berprestasi dalam organisasi dan perusahaan.

\subsection{Tanda-tanda Rendahnya Semangat Kerja}

Apabila semangat kerja dan gairah kerja karyawan memberikan banyak manfaat dan keuntungan bagi perusahaan, maka apabila terjadi penurunan semangat kerja akan mendatangkan kerugian bagi perusahaan. Sebelum semangat kerja karyawan benarbenar mengalami penurunan, perusahaan perlu mengetahui tanda-tanda penurunan semangat dan gairah bekerja karyawannya. 
Dengan mengetahui tanda-tanda tersebut, berarti perusahaan mempunyai peluang untuk menghindari kerugian yang mungkin akan timbul dikemudian hari.

Menurut Alex S. Nitisemito, dalam bukunya Manajemen Personalia (2006, p 97), adapun kecenderungan secara umum rendahnya semangat kerja adalah sebagai berikut : Tingkat absensi yang tinggi, Pada umumnya bila semangat kerja turun, karyawan akan malas untuk datang bekerja setiap hari. Apabila gejala-gejala absensi naik perlu dilakukan penelitian, yang bertujuan untuk meneliti apakah ada hal-hal lain yang mempengaruhi turunnya semangat kerja.Tingkat perpindahan karyawan yang tinggi Perlu diketahui apabila tingkat keluar masuk karyawan meningkat, hal ini menunjukkan bahwa karyawan tidak betah atau ketidaksenangan karyawan dalam bekerja pada perusahaan tersebut. Apabila dalam perusahaan sering terjadi pengunduran diri karyawan dan perekrutan karyawan baru, maka sesungguhnya akan merugikan perusahaan. Selain dapat menurunkan produktivitas, dapat pula mengganggu kelangsungan jalannya perusahaan.Tingkat produktivitas menuru dapat terjadi karena malas, menunda pekerjaan dan sebagainya. Karyawan yang semangat kerjanya turun cenderung malas melaksanakan tugasnya, sengaja menunda pekerjaan, memperlambat siapnya pekerjaan dan sebagainya. Hal ini dapat menyebabkan turunnya produktivitas. Tingkat kerusakan yang tinggi yaitu naiknya tingkat kerusakan menunjukkan bahwa perhatian dalam pekerjaan berkurang segingga terjadi kecerobohan dalam pekerjaan dan lain-lain. Meskipun demikian, naiknya tingkat kerusakan tidak mesti karena semangat kerja yang turun, tetapi banyak faktor lain seperti kerusakan mesin dan peralatan, berkutangnya pengawasan dan sebagainya, Kegelisahan dapat terwujud dari ketidaktenangan dalam bekerja, hal ini perlu diketahui oleh manajer untuk mengetahui gejala kegelisahan yang timbul, sehingga dapat dilakukan tindakan antisipasi agar tidak terjadi akibat yang lebih parah, sebab kegelisahan merupakan salah satu tanda turunnya semangat kerja.Tuntutan yang sering kali terjadisebenarnya merupakan $p$ erwujudan dari ketidakpuasan, oleh karena itu bila dalam perusahaan sering terjadi tuntutan, perusahaan tersebut harus waspada. Tuntutan yang sering terjadi merupakan tanda turunnya semangat kerja, di mana pada tahap tertentu akan menimbulkan keberanian untuk mengajukan tuntutan. Dan pemogokan merupakan tanda yang paling kuat dari perwujudan ketidakpuasan. Bila pemogokan telah memuncak dan tidak dapat dihindari lagi, maka akan menimbulkan kelumpuhan bagi perusahaan. 


\subsection{Cara Meningkatkan Semangat Kerja}

Setiap perusahaan akan selalu berusaha meningkatkan semangat kerja karyawannya semaksimal mungkin dalam batas-batas kemampuan perusahaan. Adapun cara-cara yang akan dilakukan oleh perusahaan tergantung pada situasi dan kondisi perusahaan dan tujuan yang ingin dicapai. Menurut Alex S. Nitisemito (2006, p 101), beberapa cara untuk meningkatkan semangat kerja karyawan di antaranya adalah : Gaji yang cukup, dengan gaji yang cukup, diharapkan karyawan dapat bekerja dengan tenang dan diikuti oleh semangat kerja yang tinggi. Kata "cukup" di sini sangat relatif sifatnya, bahwa jumlah gaji yang diberikan mempunyai pengaruh baik terhadap semangat kerja. Karena semakin besar gaji yang diberikan, semakin tercukupi kebutuhannya. Dengan demikian karyawan akan tetap semangat bekerja. Memperhatikan kebutuhan rohani dengan Pemenuhan pada kebutuhan rohani merupakan masalah yang berkaitan langsung dengan perasaan karyawan. Karenanya, kebutuhan rohani harus diperhatikan, seperti tersedianya tempat ibadah, kebutuhan untuk dihargai, ketentraman jiwa dan sebaginya. Dengan adanya ketentraman dalam melaksanakan pekerjaan diharapkan semangat kerja dapat ditingkatkan.
Sesekali menciptakan suasana santai dimana suasana santai diperlukan untuk menghindari rasa bosan dan tegang serta suasana kerja yang rutin bagi karyawan. Rasa bosan dan tegang, bagaimanapun akan mempengaruhi pekerjaan dan hasilnya. Oleh karena itu perusahaan perlu sesekali memberi kesempatan menikmati suasana santai pada waktu tertentu sesuai dengan kemampuan perusahaan.Memperhatikan harga diri artinya persoalan harga diri merupakan persoalan yang cukup penting. Pihak perusahaan bukan saja perlu memperhatikan harga diri, tetapi perlu juga membangkitkan dan memperhatikan harga diri karyawan. Dan menempatkan karyawan pada posisi yang tepat dimana setiap pemimpin perusahaan harus mampu menempatkan karyawan dalam bekerja pada posisi yang tepat dan sesuai dengan bidang keahlian serta keterampilan yang dimiliki masing-masing karyawan, ketidaktepatan menempatkan posisi karyawan menyebabkan pekerjaan menjadi kurang baik sehingga tidak memperoleh hasil maksimal dan semangat kerja akan menurun.

Memberi kesempatan untuk maju artinya semangat kerja akan timbul jika karyawan memiliki harapan untuk maju. Untuk itu, setiap perusahaan harus memberi kesempatan kepada karyawan untuk maju agar tercipta persaingan yang sehat. Penghargaan tersebut dpat berupa pujian, pemberian hadiah, kenaikan gaji, kenaikan jabatan dan 
sebagainya.Memperhatikan rasa aman pada masa depan jadi setiap karyawan tidak hanya memikirkan hidup untuk saat ini saja, tetapi juga memikirkan waktu yang akan datang. Semangat kerja akan terpupuk jika karyawan mempunyai perasaan aman terhadap masa depan profesinya. Untuk menciptakan rasa aman menghadapi masa depan tersebut, setiap perusahaan diharapkan dapat memberikan jaminan pensiun, uang pesangon, dan sebagainya. Dan Usahakan karyawan mempunyai loyalitas, untuk menciptakan loyalitas karyawan terhadap perusahaan, dapat diciptakan dengan cara membuat para karyawan merasa memiliki dan merasa salah satu bagian terpenting dalam perusahaan. Jika perusahaan banyak mendapatkan keuntungan sebaiknya karyawan diberikan bonus, agar para karyawan merasa diperhatikan, sehingga karywan dapat merasakan kemajuan ataupun kemunduran yang dialami perusahaan.

Sesekali karyawan perlu diajak berunding, dalam mengelola suatu perusahaan, karywan perlu dilibatkan dalam suatu perundingan, dengan demikian mereka akan ikut bertanggung jawab dan ikut memiliki perusahaan. Jika mereka merasa bertanggung jawab atas perusahaan tentunya akan bekerja lebih baik. Pemberian insentif yang terarah merupakan daya perangsang yang paling efektif sebagai pendorong untuk meningkatkan semangat kerja kerja. Akan tetapi tindakan ini perlu dijaga supaya dalam melaksanakan pekerjaannya karyawan tidak semata-mata mengejar insentif sehingga mengabaikan mutu pekerjaan. Dengan demikian perusahaan harus hati-hati, jangan sampai kebijaksanaan pemberian insentif membuat perusahaan rugi. Dan fasilitas yang menyenangkan, apabila perusahaan sanggup menyediakan fasilitas yang menyenangkan, diharapkan akan mempermudah karyawan dalam bekerja. Contoh fasilitas ini sangat banyak, seperti tersedianya kantin, tempat pengobatan, tempat ibadah, dan lain sebagainya yang dapat menimbulkan rasa senang karyawan, sehingga semangat kerja karyawan dapat ditingkatkan.

\section{ANALISA DATA DAN PEMBAHASAN}

\subsection{Analisa Data \\ Uji Validitas}

Dalam penelitian dijelaskan sebagai suatu derajat ketepatan alat ukur penelitian tentang isi atau arti sebenarnya yang diukur. Teknik yang digunakan untuk melakukan uji validitas adalah dengan korelasi Pearson Product Moment, dimana syarat minimum suatu instrument untuk dianggap valid jika nilai $r \geq$ 0,3 . Dari perhitungan dengan menggunakan SPSS di dapat hasil berikut ini : 
Tabel 1

Hasil Uji Validitas

\begin{tabular}{|c|c|c|c|c|}
\hline Pernyataan & \begin{tabular}{|c|} 
Koefision \\
Korelasi (r)
\end{tabular} & $\begin{array}{c}\text { Nilai Kritis } \\
\text { (r-tabel) }\end{array}$ & $\begin{array}{l}\text { Taraf Sig. } \\
(\alpha=0,05)\end{array}$ & Keterangan \\
\hline \multicolumn{5}{|c|}{ Motivasi Material ( X1 ) } \\
\hline Pernyataan X1_1 & 0.673 & 0.334 & 0.000 & Valid \\
\hline Pernyataan X1_2 & 0.709 & 0.334 & 0.009 & Valid \\
\hline Pernyataan X1_3 & 0.644 & 0.334 & 0.000 & Valid \\
\hline Pernyataan X1_4 & 0.448 & 0.334 & 0.007 & Valid \\
\hline Pernyataan X1_5 & 0.568 & 0.334 & 0.000 & Valid \\
\hline Pernyataan X1_6 & 0.460 & 0.334 & 0.005 & Valid \\
\hline Pernyataan X1_7 & 0.576 & 0.334 & 0.000 & Valid \\
\hline Pernyataan X1_8 & 0.529 & 0.334 & 0.001 & Valid \\
\hline \multicolumn{5}{|c|}{ Motivasi Non Material ( X2 ) } \\
\hline Pernyataan X2_1 & 0.559 & 0.334 & 0.000 & Valid \\
\hline Pernyataan X2_2 & 0.497 & 0.334 & 0.002 & Valid \\
\hline Pernyataan X2_3 & 0.599 & 0.334 & 0.000 & Valid \\
\hline Pernyataan X2_4 & 0.653 & 0.334 & 0.000 & Valid \\
\hline Pernyataan X2_5 & 0.486 & 0.334 & 0.003 & Valid \\
\hline Pernyataan X2_6 & 0.471 & 0.334 & 0.004 & Valid \\
\hline Pernyataan X2_7 & 0.469 & 0.334 & 0.004 & Valid \\
\hline Pernyataan X2_8 & 0.547 & 0.334 & 0.001 & Valid \\
\hline \multicolumn{5}{|c|}{ Semangat Kerja Karyawan ( Y1 ) } \\
\hline Pernyataan Y_1 & 0.571 & 0.334 & 0.000 & Valid \\
\hline Pernyataan Y_2 & 0.582 & 0.334 & 0.000 & Valid \\
\hline Pernyataan Y_3 & 0.497 & 0.334 & 0.002 & Valid \\
\hline Pernyataan Y_4 & 0.693 & 0.334 & 0.000 & Valid \\
\hline Pernyataan Y_5 & 0.580 & 0.334 & 0.000 & Valid \\
\hline Pernyataan Y_6 & 0.657 & 0.334 & 0.000 & Valid \\
\hline Pernyataan $Y_{-} 7$ & 0.515 & 0.334 & 0.002 & Valid \\
\hline Pernyataan Y_8 & 0.651 & 0.334 & 0.000 & Valid \\
\hline
\end{tabular}

Sumber : Hasil Pengolahan Data

Dari data-data pada tabel di atas, diketahui

bahwa bahwa butir-butir pertanyaan-

pertanyaan dari variabel Motivasi Material

$\left(\mathrm{X}_{1}\right)$, Motivasi Non Material $\left(\mathrm{X}_{2}\right)$, dan variabel Semangat Kerja Karyawan (Y) dinyatakan valid karena nilai total korelasinya (r) bernilai positif dan semuanya lebih dari 0.334 .

\subsection{Uji Reliabilitas}

Uji Reliabilitas adalah derajat ketepatan, ketelitian atau akurasi yang ditunjukan oleh instrumen

pengukuran, dengan kata lain uji reliabilitas digunakan untuk mengetahui apakah instrumen penelitian yang digunakan dapat dipercaya sebagai alat dalam pengumpulan data. Teknik penghitungan uji reliabilitas dengan melihat nilai cronbach's alpha. Suatu 
variabel dikatakan reliabel apabila nilai

alpha cronbach's $\geq 0,6$. Berdasarkan hasil penelitian diperoleh hasil seperti tercantum pada tabel di bawah ini.

Tabel 2

Hasil Pengujian Reliabilitas

\begin{tabular}{|c|c|c|c|}
\hline Pernyataan & $\begin{array}{c}\text { Cronbach's } \\
\text { Alpha if } \\
\text { item Deleted }\end{array}$ & $\begin{array}{l}\text { Rata-rata } \\
\text { Cronbach's } \\
\text { Alpha }\end{array}$ & Status \\
\hline \multicolumn{4}{|c|}{ Motivasi Material ( X1 ) } \\
\hline Pernyataan X1_1 & 0.700 & 0.739 & Reliabel \\
\hline Pernyataan X1_2 & 0.699 & 0.739 & Reliabel \\
\hline Pernyataan X1_3 & 0.706 & 0.739 & Reliabel \\
\hline Pernyataan X1_4 & 0.729 & 0.739 & Reliabel \\
\hline Pernyataan X1_5 & 0.716 & 0.739 & Reliabel \\
\hline Pernyataan X1_6 & 0.729 & 0.739 & Reliabel \\
\hline Pernyataan X1_7 & 0.719 & 0.739 & Reliabel \\
\hline Pernyataan X1_8 & 0.724 & 0.739 & Reliabel \\
\hline \multicolumn{4}{|c|}{ Motivasi Non Material ( X2 ) } \\
\hline Pernyataan X2_1 & 0.696 & 0.720 & Reliabel \\
\hline Pernyataan X2_2 & 0.701 & 0.720 & Reliabel \\
\hline Pernyataan X2_3 & 0.691 & 0.720 & Reliabel \\
\hline Pernyataan X2_4 & 0.681 & 0.720 & Reliabel \\
\hline Pernyataan X2_5 & 0.704 & 0.720 & Reliabel \\
\hline Pernyataan X2_6 & 0.705 & 0.720 & Reliabel \\
\hline Pernyataan X2_7 & 0.705 & 0.720 & Reliabel \\
\hline Pernyataan X2_8 & 0.698 & 0.720 & Reliabel \\
\hline \multicolumn{4}{|c|}{ Semangat Kerja Karyawan ( Y1 ) } \\
\hline Pernyataan Y_1 & 0.725 & 0.744 & Reliabel \\
\hline Pernyataan Y_2 & 0.722 & 0.744 & Reliabel \\
\hline Pernyataan Y_3 & 0.730 & 0.744 & Reliabel \\
\hline Pernyataan Y_4 & 0.707 & 0.744 & Reliabel \\
\hline Pernyataan Y_5 & 0.721 & 0.744 & Reliabel \\
\hline Pernyataan Y_6 & 0.711 & 0.744 & Reliabel \\
\hline Pernyataan Y_7 & 0.729 & 0.744 & Reliabel \\
\hline Pernyataan Y_8 & 0.717 & 0.744 & Reliabel \\
\hline
\end{tabular}

Sumber : Hasil Pengolahan Data

Dari data yang tertera pada tabel di atas, menunjukkan bahwa nilai cronbach's alpha kedua variabel penelitian tersebut berada di atas nilai 0,6 dengan demikian kedua variabel penelitian tersebut adalah reliabel.

\subsection{Analisis Koefisien Korelasi}

Untuk mengetahui ada tidaknya korelasi yang signifikan secara simultan antara variabel $\mathrm{X}_{1}$ (Motivasi Material) dan variabel $\mathrm{X}_{2} \quad$ (Motivasi Non Material) terhadap Semangat Kerja Karyawan PT 
Daya Adicipta Sandika. akan penulis

sajikan dalam tabel berikut ini :

Tabel 3

Hasil Pengujian Koefisien Korelasi

\begin{tabular}{|c|c|c|c|c|}
\hline & & $\begin{array}{l}\text { Motivasi } \\
\text { Material }\end{array}$ & $\begin{array}{c}\text { Motivasi Non } \\
\text { Material }\end{array}$ & $\begin{array}{c}\text { Semangat Kerja } \\
\text { Karyawan }\end{array}$ \\
\hline \multirow{4}{*}{ Motivasi Material } & Pearson Correlation & 1 & $.405^{*}$ & $.630^{\star \star}$ \\
\hline & Sig. (2-tailed) & & .016 & .000 \\
\hline & & 35 & 35 & \\
\hline & Pearson Correlation & $.405^{\star}$ & 1 & $.588^{\star *}$ \\
\hline \multirow[t]{3}{*}{ Motivasi Non Material } & Sig. (2-tailed) & .016 & & .000 \\
\hline & & 35 & 35 & 35 \\
\hline & Pearson Correlation & .630 & .588 & 1 \\
\hline \multirow{2}{*}{$\begin{array}{l}\text { Semangat Kerja } \\
\text { Karyawan }\end{array}$} & Sig. (2-tailed) & .000 & .000 & \\
\hline & $\mathrm{N}$ & 35 & 35 & 35 \\
\hline
\end{tabular}

*. Correlation is significant at the 0.05 level (2-tailed).

${ }^{* *}$. Correlation is significant at the 0.01 level (2-tailed).

Sumber : Hasil Pengolahan Data

Berdasarkan pada tabel di atas didapatkan nilai koefisien korelasi variabel $\mathrm{X}_{1}$ Motivasi Material terhadap Semangat Kerja Karyawan adalah 0,630, dan koefisien korelasi variabel $\mathrm{X}_{2}$ Motivasi Non Material terhadap Semangat Kerja Karyawan adalah 0,588, dengan demikian
Motivasi Material dan Motivasi Non Material memiliki hubungan kuat dan signifikan $(0,000<0,05)$ terhadap Semangat Kerja Karyawan PT Daya Adicipta Sandika.

\subsection{Analisa Koefisien Korelasi}

Berganda

Tabel 4

Koefisien Korelasi Berganda

Model Summary

\begin{tabular}{|c|c|c|c|c|}
\hline Model & $\mathrm{R}$ & $\mathrm{R}$ Square & $\begin{array}{c}\text { Adjusted R } \\
\text { Square }\end{array}$ & $\begin{array}{c}\text { Std. Error of the } \\
\text { Estimate }\end{array}$ \\
\hline 1 & $.728^{\mathrm{a}}$ & .529 & .500 & 1.903 \\
\hline
\end{tabular}

a. Predictors: (Constant), Motivasi Non Material , Motivasi Material

Sumber : Hasil Pengolahan Data

Analisa ini untuk menguji ada atau tidaknya pengaruh yang signifikan secara secara simultan antara variabel $\mathrm{X}_{1}$
(Motivasi Material) dan $\mathrm{X}_{2}$ (Motivasi Non Material) terhadap Semangat Kerja Karyawan PT Daya Adicipta Sandika. 
Berdasarkan pada tabel di atas didapatkan bahwa nilai korelasi berganda 0,728. Dengan demikian Motivasi Material dan Motivasi Non Material mempunyai hubungan kuat dan positif terhadap Semangat Kerja Karyawan PT Daya Adicipta Sandika.

\subsection{Analisis Koefisien Penentu}

\section{(Determinasi)}

Untuk mengetahui berapa besarnya kontribusi antara $\mathrm{X}_{1}$ (Motivasi Material) dan $\mathrm{X}_{2}$ (Motivasi Non Material) terhadap variabel terikat $\mathrm{Y}$ (Semangat Kerja Karyawan), dengan aplikasi program SPSS, didapat hasil sebagai berikut.

Tabel 5

Hasil Pengujian Koefisien Determinasi Model Summary

\begin{tabular}{|c|r|r|r|r|}
\hline Model & R & R Square & $\begin{array}{c}\text { Adjusted R } \\
\text { Square }\end{array}$ & $\begin{array}{c}\text { Std. Error of the } \\
\text { Estimate }\end{array}$ \\
\hline 1 & $.728^{\mathrm{a}}$ & .529 & .500 & 1.903 \\
\hline
\end{tabular}

a. Predictors: (Constant), Motivasi Non Material , Motivasi Material

Sumber : Hasil Pengolahan Data

Dari data yang tertera pada tabel di atas, menunjukkan bahwa nilai Koefisien Penentu/ Determinasi $\left(\mathrm{R}^{2}\right)$ Semangat Kerja Karyawan adalah 0,529 dengan demikian kontribusi variabel $\mathrm{X}_{1}$ (Motivasi Material) dan variabel $\mathrm{X}_{2}$ (Motivasi Non Material) memiliki kontribusi sebesar 52,9\% terhadap variabel Y (Semangat Kerja Karyawan) di PT Daya Adicipta Sandika dan sisanya sebesar $47,1 \%$ dipengaruhi dari factor-faktor lain yang tidak penulis diteliti, misalnya kepemimpinan, stres kerja, dan hubungan kerjasama antar karyawan.

\subsection{Pengujian Regresi Linier}

\section{Berganda}

Untuk mengetahui pengaruh variabel bebas (Motivasi Material dan Motivasi Non Material) terhadap variabel terikat (Semangat Kerja Karyawan) di PT Daya Adicipta Sandika, digunakan rumus regresi linier berganda. Rekapitulasi hasil analisa regresi linier berganda dapat dilihat pada tabel berikut: 
Tabel 6

Rekapitulasi Hasil Analisa Regresi Berganda

Coefficients $^{\mathrm{a}}$

\begin{tabular}{|c|c|c|c|c|c|}
\hline \multirow[t]{2}{*}{ Model } & \multicolumn{2}{|c|}{$\begin{array}{c}\text { Unstandardized } \\
\text { Coefficients }\end{array}$} & $\begin{array}{l}\text { Standardized } \\
\text { Coefficients }\end{array}$ & \multirow[t]{2}{*}{$\mathrm{t}$} & \multirow[t]{2}{*}{ Sig. } \\
\hline & B & Std. Error & Beta & & \\
\hline (Constant) & 1.717 & 5.578 & & .308 & .760 \\
\hline Motivasi Material & .446 & .126 & .469 & 3.535 & .001 \\
\hline $\begin{array}{l}\text { Motivasi Non } \\
\text { Material }\end{array}$ & .502 & .167 & .398 & 3.000 & .005 \\
\hline
\end{tabular}

a. Dependent Variable: Semangat Kerja Karyawan

Sumber : Hasil Pengolahan Data

Berdasarkan data-data pada tabel di atas, maka dapat dihasilkan persamaan regresi linier berganda, yaitu : $Y=\mathbf{1 . 7 1 7}+\mathbf{0 . 4 4 6}$ $\mathrm{X}_{1}+\mathbf{0 . 5 0 2 X _ { 2 }}$

Dalam persamaan regresi tersebut diketahui konstantanya adalah 1.717 ini dapat diartikan bahwa tanpa adanya Motivasi Material $\left(\mathrm{X}_{1}\right)$, dan Motivasi Non Material $\left(\mathrm{X}_{2}\right)$, maka (Semangat Kerja Karyawan) di PT Daya Adicipta Sandika (Y) menunjukkan nilai sebesar 1.717 poin/satuan.

Koefisien regresi $\mathrm{X}_{1}(0.446)$, artinya jika Motivasi Material nilainya dinaikkan 1 point/satuan, sementara Motivasi Non Material nilainya tetap, maka (Semangat Kerja Karyawan) di PT Daya Adicipta Sandika (Y) akan naik 0.446 point/satuan. Koefisien regresi $X_{2}(0.502)$, artinya jika Motivasi Non Material nilainya dinaikkan 1 point/satuan, sementara Motivasi Material nilainya tetap, maka Semangat
Kerja Karyawan di PT Daya Adicipta Sandika (Y) akan naik 0.502 point/satuan.

\subsection{Teknik Analisa Uji Hipotesis}

Uji F

Uji $F$ dilakukan untuk melihat signifikansi pengaruh variabel bebas secara serentak terhadap variabel terikat. Pengujian ini dilakukan dengan membandingkan nilai signifikan $\mathrm{F}$ hitung.

Adapun rumusan hipotesanya adalah sebagai berikut :

1) Ho Motivasi material dan motivasi non material secara simultan tidak berpengaruh signifikan terhadap semangat kerja karyawan pada PT Daya Adicipta Sandika.

2) Ha Motivasi material dan motivasi non material secara simultan berpengaruh signifikan terhadap semangat kerja karyawan pada PT Daya Adicipta Sandika. 
Tabel 7

Hasil Uji F

ANOVA $^{\mathrm{a}}$

\begin{tabular}{|c|c|c|c|c|c|}
\hline Model & $\begin{array}{l}\text { Sum of } \\
\text { Squares }\end{array}$ & $\mathrm{df}$ & $\begin{array}{c}\text { Mean } \\
\text { Square }\end{array}$ & $\mathrm{F}$ & Sig. \\
\hline Regression & 130.379 & 2 & 65.189 & 17.998 & $.000^{\mathrm{b}}$ \\
\hline Residual & 115.907 & 32 & 3.622 & & \\
\hline Total & 246.286 & 34 & & & \\
\hline
\end{tabular}

a. Dependent Variable: Semangat Kerja Karyawan

b. Predictors: (Constant), Motivasi Non Material , Motivasi Material

Sumber : Hasil Pengolahan Data

Berdasarkan tabel di atas diketahui bahwa signifikan variabel $\mathrm{X}_{1}$ yaitu Motivasi material serta variabel $\mathrm{X}_{2}$ Motivasi non material adalah sebesar $0,000<0,05$ dengan demikian Ho ditolak dan $\mathrm{Ha}$ diterima artinya secara simultan Motivasi material dan motivasi non material berpengaruh signifikan terhadap semangat kerja karyawan pada PT Daya Adicipta Sandika

\section{b. Uji t}

Uji $\mathrm{t}$ dilakukan untuk melihat signifikansi pengaruh variabel bebas secara sendiri-sendiri (parsial) terhadap variabel terikat dengan menggangap variabel lain bersifat konstan. Pengujian ini dilakukan dengan membandingkan nilai sig. $\mathrm{t}$ hitung masing-masing variabel bebas. Adapun rumusan hipotesanya adalah:
1) Ho Motivasi Material secara parsial tidak berpengaruh signifikan terhadap Semangat Kerja Karyawan di PT Daya Adicipta Sandika.

2) Ho Motivasi Non Material secara parsial tidak berpengaruh signifikan terhadap Semangat Kerja Karyawan di PT Daya Adicipta Sandika.

3) Ha Motivasi Material secara parsial berpengaruh signifikan terhadap terhadap Semangat Kerja Karyawan di PT Daya Adicipta Sandika.

4) Ha Motivasi Non Material secara parsial berpengaruh signifikan terhadap terhadap Semangat Kerja Karyawan di PT Daya Adicipta Sandika. 
Tabel 8

Uji t

Coefficients $^{\mathrm{a}}$

\begin{tabular}{|c|c|c|c|c|c|c|}
\hline \multirow{2}{*}{\multicolumn{2}{|c|}{ Model }} & \multicolumn{2}{|c|}{$\begin{array}{c}\text { Unstandardized } \\
\text { Coefficients }\end{array}$} & $\begin{array}{c}\text { Standardized } \\
\text { Coefficients } \\
\end{array}$ & \multirow[t]{2}{*}{$\mathrm{t}$} & \multirow[t]{2}{*}{ Sig. } \\
\hline & & $\mathrm{B}$ & Std. Error & Beta & & \\
\hline \multirow{3}{*}{1} & (Constant) & 1.717 & 5.578 & & .308 & .760 \\
\hline & Motivasi Material & .446 & .126 & .469 & 3.535 & .001 \\
\hline & Motivasi Non Material & .502 & .167 & .398 & 3.000 & .005 \\
\hline
\end{tabular}

a. Dependent Variable: Semangat Kerja Karyawan

Sumber : Hasil Pengolahan Data

1. Berdasarkan hasil penelitian yang tertera pada tabel di atas, diketahui bahwa nilai signifikan variabel $\mathrm{X}_{1}$ Motivasi Material adalah sebesar 0,001 $<5 \%,(0,001<0,05)$ maka $\mathrm{Ha}$ (hipotesis alternatif) diterima dan Ho (hipotesis nihil) ditolak. Artinya Motivasi Material secara parsial berpengaruh signifikan terhadap Semangat Kerja Karyawan di PT Daya Adicipta Sandika.

2. Nilai signifikan untuk variabel $\mathrm{X}_{2}$ Motivasi Non Material $0.005<5 \%$, $(0,005<0,05)$. Artinya variabel $\mathrm{X}_{2}$ Motivasi Non Material secara parsial berpengaruh signifikan terhadap terhadap Semangat Kerja Karyawan di PT Daya Adicipta Sandika.

\section{PENUTUP}

\subsection{Kesimpulan}

Berdasarkan pada analisis dan pembahasan yang telah diuraikan pada bab sebelumnya, maka kesimpulannya adalah sebagai berikut :
1. Berdasarkan hasil analisa koefisien korelasi Hasil analisis koefisien korelasI didapatkan nilai koefisien korelasi $\mathrm{X}_{1}$ Motivasi Material terhadap Semangat Kerja Karyawan adalah 0,630, dan koefisien korelasi variabel $\mathrm{X}_{2}$ Motivasi Non Material terhadap Semangat Kerja Karyawan adalah 0,588, dengan demikian Motivasi Material dan Motivasi Non Material memiliki hubungan kuat dan signifikan $(0,000<0,05)$ terhadap Semangat Kerja Karyawan PT Daya Adicipta Sandika,

2. Hasil analisa koefisien determinasi didapat nilai $\left(\mathrm{R}^{2}\right)=0,529$, dengan demikian variabel $\mathrm{X}_{1}$ (Motivasi Material) dan variabel $\mathrm{X}_{2}$ (Motivasi Non Material) memiliki kontribusi sebesar $52,9 \%$ terhadap variabel $\mathrm{Y}$ (Semangat Kerja Karyawan) di PT Daya Adicipta Sandika dan sisanya sebesar $47,1 \%$ dipengaruhi dari factorfaktor lain yang tidak penulis diteliti, misalnya pengaruh kepemimpinan, 
stres kerja, dan hubungan kerjasama antar

3. Berdasarkan hasil uji analisa regresi linier berganda didapatkan persamaan regresi linier berganda : $\mathbf{Y}=\mathbf{1 . 7 1 7}+$ $0.446 X_{1}+0.502 X_{2} a=1.717$ ini dapat diartikan bahwa tanpa adanya Motivasi Material $\left(\mathrm{X}_{1}\right)$, dan Motivasi Non Material $\left(\mathrm{X}_{2}\right)$, maka (Semangat Kerja Karyawan) di PT Daya Adicipta Sandika (Y) menunjukkan nilai sebesar 1.717 poin/satuan, dan $b 1=0.446$, artinya jika Motivasi Material nilainya dinaikkan 1 point/satuan, sementara Motivasi Non Material nilainya tetap, maka (Semangat Kerja Karyawan) di PT Daya Adicipta Sandika (Y) akan naik 0.446 point/satuan serta b2 $=0.502$, artinya jika Motivasi Non Material nilainya dinaikkan 1 point/satuan, sementara Motivasi Material nilainya tetap, maka Semangat Kerja Karyawan di PT Daya Adicipta Sandika (Y) akan naik 0.502 point/satuan

4. Selanjutnya dalam pengujian hipotesis penelitian yang digunakann dengan uji Uji F diketahui bahwa Motivasi material dan motivasi non material berpengaruh signifikan terhadap semangat kerja karyawan pada PT Daya Adicipta Sandika, karena nilai sig. F hitung adalah 0.000 , artinya $<5 \%$, $(0.000<0.005)$. Dengan demikian Ho ditolak dan Ha diterima, sehingga dapat disimpulkan bahwa variabel bebas secara simultan berpengaruh signifikan terhadap variabel terikat.

5. Sedangkan berdasarkan Uji T diperoleh hasil $: \mathrm{Ha}=$ Nilai signifikan variabel $\mathrm{X}_{1}$ Motivasi Material adalah sebesar $0,001<5 \%,(0,001<0,05)$ maka Ha (hipotesis alternatif) diterima dan Ho (hipotesis nihil) ditolak. Artinya Motivasi Material secara parsial berpengaruh signifikan terhadap terhadap Semangat Kerja Karyawan di PT Daya Adicipta Sandika, dan Ha = Nilai signifikan untuk variabel $\mathrm{X}_{2}$ Motivasi Non Material $0.005<5 \%$, $(0,005<0,05)$. Artinya variabel $\mathrm{X}_{2}$ Motivasi Non Material secara parsial berpengaruh signifikan terhadap terhadap Semangat Kerja Karyawan di PT Daya Adicipta Sandika.

\subsection{Saran}

Saran-saran yang dapat penulis sampaikan melalui hasil penelitian ini di antaranya:

1. Hendaknya Perusahaan memberikan kompensasi kepada karyawan yang disesuaikan dengan prestasi kerja dan dalam taraf wajar sebagai suatu motivasi yang bersifat material untuk mendorong semangat kerja karyawan.

2. Hendaknya Perusahaan memberikan apresiasi kepada karyawan yang telah berprestasi, dengan memberikan penghargaan misalnya berupa 
kesempatan untuk mengembangkan diri

sehingga karyawan terpacu untuk bekerja lebih giat.

\section{DAFTAR PUSTAKA}

Anwar Prabu Mangkunegara, 2005, Evaluasi Kinerja SDM, Penerbit PT Refika Aditama, Bandung.

Alex S, Nitisemito, 2006, Manajemen Personalia, Edisi ke 4, Ghalia Indonesia, Jakarta.

Dessler, Gerry, 2004, Manajemen Sumber Daya Manusia, Edisi kesembilan, Penerbit PT. Indeks Kelompok Gramedia, Jakarta, 472 halaman

Heidjrachman dan Suad Husnan. 2008, Manajemen Personalia, Edisi 4,
Cetakan Kesebelas, BPFE, Yogyakarta.

J. Supranto, 2008, Statistika Teori dan Aplikasi, Jilid Satu, Edisi Ketujuh, Penerbit Erlangga, Jakarta, 392 halaman.

Malayu SP. Hasibuan, 2006, Manajemen Sumber Daya Manusia, Edisi Revisi, Penerbit Bumi Aksara, Jakarta 273 halaman.

Manullang, M., 2005, Dasar-dasar Manajemen, Gadjah Mada University Press, Yogyakarta.

Sugiono, 2010, Metode Penelitian Kuantitatif Kualitatif dan R\&D, Penerbit Alfabeta, Bandung, 380 halaman.

T. Hani Handoko, 2008, Manajemen Personalia dan Sumber Daya Manusia, BPFE, Yogyakarta. 